\title{
Brief Concepts and Philosophies of Different Authorities on the Crucial and Dynamic Aspect of Entrepreneurship in India
}

Ullah $\mathbf{R}^{*}$

School of Business Administration, South western University of Finance and Economics, Chengdu, China

\begin{abstract}
The general aspect of entrepreneurship and its theory has gradually evolved in the past two centuries. Nonetheless, in the long transformation mainly during which a given society change from the presence of tribalism to the selfsustained economic prosperity, the closely shaped political, the social and economic based strands of the social fabric that changed their various patterns and also their relationships. In addition, the aspect of entrepreneurship within the plural and the social-oriented stratified communities like India is harder and also intriguing. Nonetheless, the impetus of this paper is to focus on the process of presenting brief concepts and philosophies of different authorities on the crucial and dynamic aspect of entrepreneurship. Entrepreneurship does play a vital role in the creation of an Avenue for the process of employability for rural-based societies, offering chances for people who are willing to venture into business and consequently it does improve the rural sector. The entrepreneurs who are in rural settings have changed their avenues into trading zones hence enabling them to become urban settings.
\end{abstract}

Keywords: Entrepreneurship; Relationships; Business; Economic

\section{Introduction}

Over the past few decades, there have been various endeavors to define entrepreneurship [1]. The more typical description of the term entrepreneurship is most inclined towards the functional mandate of entrepreneurs and comprise of innovation, capital supply, decisionmaking process, uncertainty-bearing, the allocation of resources and ownership [2]. Fundamentally, entrepreneurship can be said to be a type of behavioral expression of an individual and entrepreneurs commonly depict it only in some phases of their career.

Entrepreneurship can be seen as a function of knowledge and also flexibility, two fundamental factors which have a clear competitive advantage in the global economy that is drastically increasing. The radical change in relation to the structure of the industry towards the lens of more decentralized settings that many of the OECD nations went through during the mid-1970s and the early 1990s is a clear reflector of this particular development [3]. Drastic technological advancement and also the presence of intense global based competition which emanated from globalization and the economic liberalization has entirely validated the proposition that enhancing entrepreneurship implies enhancing a nation's competitiveness.

\section{The Relationship between Entrepreneurship and Economic Growth}

\section{Theoretical evidence}

The entrepreneur has been a fundamental element in almost all types of production, distribution and growth propositions. The primary duty of entrepreneurship as an integral element that fosters economic growth is entirely explicit as noted by Joseph Schumpeter in his theory [4]. According to the mentioned, every individual can be termed as an entrepreneur provided they execute a new type of combination. The process of discovering these combinations is a process of entrepreneurial innovation which will foster the development of the economy. These different activities of developing new combination are entirely nothing but a process of devising better approaches to meet the prevailing demand or to develop new commodities, in the process rendering the contemporary commodities to be entirely obsolete.
The business of the innovative entrepreneur will, as a result, grow through a dual process of snatching the market share from the existing members and enhance an overall requirement for the commodities presented in the whole market. Thus, the general aspect of creative destruction is much fostered by the conscious entrepreneurial endeavor to have a radical change in the market dynamics and can be an instrumental approach for innovation and profit margin possibilities. In relation to this particular concept of innovative destruction, Schumpeter devised a well-stated theoretical point of view for long waves of business cycles and also the economic oriented growth [5]. Notably, any business cycle can be seen as a product of innovation that comprises of the creation of new aspects and its implementation in a new commodity, process or service, which leads to a positive development of the economy of the country, foster the rates of employment and establish profits for an innovative business venture.

It is globally acknowledged that growing economies do develop through the accumulation of the human and physical capital and also the presence of specialization. In the event that an economy has joined the industrialized stage, it is commonplace to note a qualitative shift in relation to the primary drivers of the economic development taking place [4]. In other advanced industrial based economies, the general process of technical innovation and also collective concepts that are fostered by the R\&D endeavors look to be paramount.

Schmitz offers a distinct model in which the various actions that are executed by entrepreneurs are the basic determinants of productivity and also growth. The model does concentrate on the specific obligation

*Corresponding author: Ullah R, School of Business Administration, South western University of Finance and Economics, Chengdu, China, Tel: +8615802875733. E-mail: rehanmalakand@gmail.com

Recieved October 11, 2018; Accepted November 14, 2018; Published November 22, 2018

Citation: Ullah R (2018) Brief Concepts and Philosophies of Different Authorities on the Crucial and Dynamic Aspect of Entrepreneurship in India. J Entrepren Organiz Manag 7: 249. doi: 10.4172/2169-026X.1000249

Copyright: (c) 2018 Ullah R. This is an open-access article distributed under the terms of the Creative Commons Attribution License, which permits unrestricted use, distribution, and reproduction in any medium, provided the original author and source are credited. 
of imitative activities that are carried out by the entrepreneurs. This type of concentration is attained from the growth experience of various economies, showing that it is less the process of innovation by the entrepreneur as revealed by Schumpeter when juxtaposition to the imitating entrepreneur who has a contribution to the development of the economy [5]. The imitating entrepreneurs are the kind of entrepreneurs who see and imitate the existing processes and activities and further implement them.

\section{Entrepreneurship-the scenario of India}

It is fundamental to note that the global-based entrepreneurial firm, TiE and also the KPMG in the country of India carried out a study that was aimed at measuring the confidence of the entrepreneurs across ten different states across India. Based entirely on the point of view of the entrepreneurs, instead of any factual examination of the factors, the primary objective of the research was to identify the factors that are involved and them benchmark the growth of the conducive environment in which entrepreneurs operated across India [6]. The conclusion of the study is that things in India are heading in the right direction. However, it is important to highlight that the majority of the entrepreneurs still have a lot of expectations when it comes to the kind of environment in which they are operating as affirmed by Meyer et al. [7]. The study further enforced the largely held presumption that the Risk Capital is widely not still present in the required amount and the governance challenges and local business settings receive failing grades.

The drastic change in the business working climate across the country of India can be measured from the context that the country is perceived to be one of the best nations to invest across the globe. It is apparent that majority of the companies in the recent years are looking to invest largely in startups and early-stage firms across India [8].

\section{Participants}

The National Knowledge Commission (NKC) in India carried out a comprehensive research on entrepreneurship. Based on the drafted report by the commission, it is worthwhile noting that a successful entrepreneurial environment is the function of various elements that work in tandem. The primary entrepreneurial triggers comprise of: personal motivations, socio-cultural elements, business environment and the Access to the early-stage capital education [9].

The main motivation for instigators is independence, market opportunities, new concepts, family status, dream and challenge. Motivation instigators are distinct based on various parameters such as place, sex, age, family status and work experience. The participants who took part in the study were business entrepreneurs who are established and also the prospective entrepreneurs. According to the findings of the research, the primary challenge in relation to starting a business in the country is the principal motivation element [10]. One of the primary findings is that around $99.4 \%$ of all the entrepreneurial participants who were interviewed never ascribed to the notion of a routine job, which fostered them towards establishing a business venture. The support from family in this given case is noted to be of crucial importance, with around $74 \%$ of all the entrepreneurs agreeing that they got such support.

Further, $63 \%$ of all the participants asserted that they financed their ventures, while other sources of finance comprised of banks, the venture capital, state finance agencies and angel investors. Among the entrepreneurs who access finance from banks, the majority of them (61\%) who approached the banking institutions acquired did get support from the banks. Yet still, there is a largely held proposition among the various entrepreneurs that it is very hard to access bank loans at the start-up stage while at the same time becoming comparatively easier during the development state [11].

It is imperative to highlight that education is perceived as the primary factor contributing to success with above $95 \%$ of all the participants were convinced that education is the primary trigger to foster entrepreneurial inclinations. 98\% of all the entrepreneurs are graduates. Nonetheless, around $16 \%$ focused on a particular sector due to their educational background.

The hiring of the workforce and retention process was seen as one of the primary challenges. Above one-third of all the participants encountered challenges in the process of accessing and also in the retention of the workforce. $50 \%$ of the participants, encountered challenges while looking for policy clearances and also licensing [5]. Another apparent challenge was the accessibility of crucial information in relation to the registration approaches, finance and also other key schemes. $56 \%$ of the interviewed entrepreneurs asserted that the paucity of the quality of the infrastructure- mainly power, telecommunications and transport was a major obstacle.

\section{Rationale of the Study}

Consistent development of the business activity is one of the primary goals of any state. Given the contemporary difficulties that are encountered by the majority of the nations to make sure that there is advancement in the development of jobs, the increase in the entrepreneurship activity that leads to the creation of wealth and economic development. In addition, the presence of more business ventures implies a higher level of job creation, which is in the interest of the lawmakers. The right decision to venture into business is propelled by both the extrinsic and intrinsic elements. It is typically easier to comprehend the general impact of the various factors that are intrinsic to the business like the demand and supply, the competition, cost of resources, competition, labor force, and cost of capital and availability of resources among others. In the event that many of the mentioned factors are fundamentally favorable, the chances of individuals going into business are relatively high [12]. Nonetheless, the impact of environmental elements is not a well-comprehended avenue. According to documented studies appreciates the objective of the external factors, mostly the environment, but it fails to offer a deep kind of reflection on the influence of such key factors.

As such, it is apparent that there a wide scope of research on the impact of environmental aspect on the decision-making process of taking up the work of entrepreneurship.

\section{Problem Statement}

The country of India, in essence, is blessed with adequate natural resources, the geographical advantages and intellectual capital, some of the primary elements that can majorly have a favorable impact on entrepreneurship. In the past few decades, these resources have been innovatively employed by countless workforce form to develop new ventures that changed the general socio-economic landscape of the entire region.

Across the globe, there is dire need to foster the environment to propel greater business success. To put this into perspective, The United States Company Silicon Valley prosperity story in relation to the promotion of new startup ventures has been associated with the presence of a conducive set of environmental elements. The country of India, in essence, is yet to be fully developed, but it is gradually moving 
towards achieving the status of an economic superpower nation. The scale of the contribution of entrepreneurship has also been a fundamental element in the growth of the economy of India and it is as such expected to be so in the few years to come as noted by Schumpeter [13].

It is evident that there is a paucity of research in comprehending regional environmental elements that do have an implication on the success of the business, especially in relation to India.

\section{The Objective of the Research}

The following goals are noted in relation to Entrepreneurship Environment.

1. To easily identify the fundamental elements that creates the support for an entrepreneur.

2. To investigate the support that is needed by the prospective entrepreneur to venture into business.

3. To investigate the support systems that is needed by the young prospective entrepreneurs and startup business individuals.

4. To explore the variation that exists between potential and existing business individuals in relation to the support system elements.

\section{The Limitation of the Study}

The main study research data was acquired from the potential and established entrepreneurs. While care is largely taken to access concise response, the subjective factor in response could not be entirely be eradicated.

In a business environment, various stakeholders foster the success or the failure of the entire system. It comprises of the family of the entrepreneurs, the various venture capitalist, state agencies, angel investors and also the bureaucrats in the government. The research will not entirely cover all the stakeholders.

\section{The Literature Review}

\section{Introduction}

Business venture plays a fundamental role in the creation of an avenue that will create jobs for the people in rural settings, offering opportunities for individuals who focus on enterprises and enhancing the status of the social context especially in the rural settings. The scale of business in the contemporary times has transformed the lives of the majority of the people in business into being prosperous people and generates financial income for the rural settings. Business people mainly in the underdeveloped places in most cases have enhanced their business scales into business avenues that have transitioned such areas into descent urban places [14].

Carrying out a study is a critical element of understanding the transition in areas that are yet to develop. Having background information in entrepreneurship theory is instrumental in enabling an individual to have a conceptualization of the issue, carrying out a research and the interpretation of the findings. The research carried out shows the implication of the business roles of the country of India and also other nations. In the research, it is apparent that the aspect and concept of business has been employed in the various sense by studies compiled in other countries across the globe and also in India.

Entrepreneurship growth in PURA scheme villages in India: The economic based liberalization that was started in the last decade of the 20th century has attained a momentum in the past few years as noted by the development rate of approximately eight percent of the total Gross Domestic Product. Nonetheless, the advantages of this particular growth are mostly found in urban cities, neglecting the rural settings [15]. Inadequacy of fundamental resources that people require on daily basis is one of the primary reasons why the majority of the people who resided in the places that were deemed to be underdeveloped to migrate to the urban areas in such of better living standards [16].

The various villages in Tamil Nadu received a lot of support from the local administration through the respective Panchayats [17]. The majority of the programs were instituted by the state and other wiling organizations across the country to enhance business ventures among the prospective individuals who wanted to engage themselves in business ventures. The main objective of the establishment of PURA is to offer services to the marginalized communities. The program is a crucial aspect that many of the local based colleges and nongovernment agencies have taken a milestone in the provision of the amenities to the marginalized places to transform into urban settings through development [18].

\section{Objective of PURA}

- The identification and addressing of the socio based economic requirements of the villages.

- The sustainable employment of land, energy, water and other present bio-resources.

- The development of the infrastructure resources such as the markets, power, roads, institution and small scaled sectors.

- Value addition to commodities for employment and the production of income.

- The dissemination of the technical knowledge and do-how apart from the social values.

Information connections: Fundamental information and abilities in the recent years have in context fostered the development of the various marginalized regions through the institution of programs. The education and training programs were inclined towards electronic associations in which the natives of the village were on a position to get themselves connected to the various subjects.

\section{Entrepreneurship growth in rural areas of international states}

The development of marginalized regions such as Mississippi Delta and Grande Valley of United States were always perceived to largely lag behind in terms of development. Different approaches and models were employed in the process of examining the primary factor that led to the underdevelopment of business ventures [19]. The majority of the people have named the place the Black Belt due to the fact that the majority of the people who inhabited the regions were Africans. The primary reason that fostered under development of ventures was the fact that there was limited training and education that was offered to the people to understand the dynamics of the business world in a proper way. It led to poor performance of the entrepreneurial activities as noted by Robinson, et al. [11].

The Global Entrepreneurship Monitor (GEM) does monitor the scale of business processes of the nations of the continent of Asia and also the obligation that the majority of the entrepreneurs play in the growth of the economy in the rural settings. Cross-sectional examinations that were employed in the investigation of the data acquired from the GEM shows that the fundamental role of the state 
and international based institution in the support of businesses hence fostering the economic growth [20].

\section{The establishment of the research niche}

Critical examination of research in relation to the business development clearly reveals the aspect of the different business roles that have shifted the attention to the various management areas. It is worthwhile mentioning that entrepreneurship can be perceived as an entirely unexplored area of study that is not beyond twenty to twentyfive years. In the past few decades, this particular field has attracted a lot of interests that are beyond the typical areas of management studies as noted by Cornelius, et al. [21]. Similar to many other fields of research through the lens of social orientations, business study contains its central background in the development of the various transformations that are visible in the community. In the majority of the states, mainly Europe, entrepreneurship has gradually become a crucial tool that can be employed to find solution to the challenges that affects the development of the country and other regions [22].

A critical examination of research concerning entrepreneurship growth in India shows that the majority of the studies that are being carried out are inclined towards business ventures especially in the marginalized regions and growth as a fundamental apparatus that is utilized to resolve the issues related to poverty. In essence, selfemployment, the inventor-entrepreneurs has in context fostered the marginalized communities to concentrate on business [23]. The growth of women venturing into business has received a lot of coverage in the majority of studies of India concerning entrepreneurial activities. The literature entirely concentrates widely on economic development through the scope of entrepreneurship and also the support for the government of India [24]. The research uses complex statistical apparatus to clearly establish the actual intentions of business growth, the attributes of business people who have taken up business roles and the characteristics of the under-developed places that in the long run are turned into areas that witness drastic growths and development.

\section{Research Methodology}

\section{Introduction}

The current study does focus on the process of endeavoring to comprehend and document the various two dimensions of the rurally inclined entrepreneurship creation initiatives and the interventions in the various documented places.

1. Performance examination of the chosen development agencies in relation to the REDPs.

2. The performance examination of the chosen development schemes of development organizations.

The study creates an explicit attempt to elucidate entrepreneurial creation in an approach that may be applied to an evaluation of the rural economic creation attempt. The entire goals of the research is to investigate and examine the socio-economic implication and the performance of the different government schemes, different programs and institutional based support in the process of attaining the target of propelling rural based entrepreneurship and promote, support and sustain given entrepreneurs and the micro and small based village premises in the state of Haryana. The documented goals are inclined towards the following;

1. The process of documenting the institutional based network and the involvement of the support organizations, profiling the chosen entrepreneurship development institutions and the documentation of the various entrepreneurship development programs, the policies and also the schemes, especially in Haryana.

2. The documentation of the various credit and financial help, management and technical help, infrastructural support and education of entrepreneurship and training offered by the development firms to the prospective rural business in Haryana.

3. The examination of the performance of development programs and also other implications on the economic well-being in the rural setting, development of the SSI and village companies in the State, and the generation of the employment chances in the rural settings of Haryana.

The rationale of the study: The aspect of the rurally based entrepreneurship creation has remained almost unexamined in India and also at the larger scale of Asia in general. One particular unexamined area is that the Indian rural economy and also the rural industrial setting that has gradually been witnessing the futile endeavors of the various lawmakers and supporting organizations that are meant for propelling rural entrepreneurship creation in the country. At the same instance, the nation is in the midst of coping with the scale of globalization and the liberalization. It is important to note that the transition process is harder for rural industrialization law scenario itself which is vague to them. Therefore, to easily diffuse the comprehension of the aspect of rural entrepreneurship development and the examination of the performance and the implication of supporting organizational network and government growth schemes that have become the basic need of the hour.

The entrepreneurship and entrepreneurship growth is often stressed as being an integral element for the socio-economic based development of rural India setting and the alleviation of poverty according to Nidheesh [25], yet still, it is entirely neglected in relation to the aspect of Rural entrepreneurship and also rural entrepreneurship growth. Only a few researches have focused on the construction of the rural entrepreneurship and also rural entrepreneurship growth and its implication on the rural socio-economic of the country and the human growth [26]. Despite the fact that some of the noteworthy research in this field has been carried out by various scholars, there has been less kind of interest in researching the links that exists between the performance and the implication of rural entrepreneurship growth endeavors with the reference to job generation, development of micro and small village businesses and the socio-economic uplifting of the rural individuals [27]. So as to address the presence of such niche, apart from direct effect, this research is also carried out to investigate the various indirect implications of rural entrepreneurship development programs and various schemes which concern the socio-economic prosperity of the rural individuals. It is in this particular context that the person carrying out the research opted to incubate the current study mainly in the context of the rural Haryana.

The research endeavors to add incrementally to the present literature in three critical approaches. First, very few research that have been executed to investigate the impact of the rural entrepreneurship development programs of the different development and also the support for the organization on promotion, creation and sustenance of the micro and the small village businesses and the employment generation, so important for the socio-economic and the industrial growth of the rural fields, has never been the integral subject of such 
research operations [28]. Secondly, an indirect implication of the rural entrepreneurship development approaches, arbitrated by the socioeconomic results in the form of micro and small village programs, is examined for the first time. Lastly, while investigating the connection that exists between performance of the chosen rural entrepreneurship development organizations and the state agencies and its outcome of the socio-economic and the employment results, this study does make use of the various responses both from those who benefited and the people who come from such organizations that are responsible for the required physical and financial results. It may serve as the main objective to assist in the process of validating the previous outcome and financial results. It may serve the role of validating the previous outcome, whereby the noted policy framework of the state, supporting various institutional connection and the various schemes and programs that are triggered over a given duration that was inclined towards the process of alleviating poverty and employment generations alone.

The examination is mainly an integral component of the planning process. The various plan schemes are developed at the State Level Planning and the implementation across the country without enough comprehension of the project zone, the target group, local organization and the attitude of the people who are in charge of the implementation process. Response from evaluation research offers an essential input for evaluation of the correctness of the design of the scheme and the implementation approach. It enables, if fundamental, outing in place the right corrective approaches that will be essential to foster the levels of performance. It is the rationale for taking up such researches.

\section{Statement of the problem}

It is important to note that entrepreneurship is something that ought to be taken up with courage and passion. It also offers some of the fundamental skills like executing things in advance, in an innovative approach and with a lot of care and also professionalism. The current research is focused on the scale of entrepreneurial obstacles and success elements in utility services ventures in the city of Chennai. It is particularly and connected with the natural based capacity of the women and it is not entirely capital intensive. Majority of the studies shows that, in the service-intensive ventures, many of the women are largely successful as a result of their natural based capacity to tackle things in a soft approach [29]. There are various researches on the limited service such as the beauty care, the health-based diagnostics, and the Petty premise like tailoring among others. No particular comprehensive research is found covering ten typical utility services engaged by the various women as basically an entrepreneurial business and also the study entirely issues linked with those and the identification of success variables. As such, it is further a value addition to the present literature and offers wider comprehension of the entrepreneurial obstacles and success elements in the utility service business in the city of Chennai [29].

\section{Data collection methods and tools}

The approaches of collecting primary and secondary data are different due to the fact that the primary data are to be collected originally, while in the case of the secondary data, the type and nature of the data being collected are typically that of compilation. This section will highlight the data research methods that were used [30].

\section{Sampling method}

In pursuance of the documented goals, proposition and information requirement, the data for the research has been collected through the use of multi-stage random sampling approach.
Choosing of SHGs and respondents: It is imperative to note that the sample unit which is the respondent for the collection of the primary data consists of the program beneficiaries who were either personal beneficiaries or the particular member of SHGs. The SHGs were selected in case of the various schemes like the REGP, SGSY and the BLP since the scheme involve a particular mechanism of fostering microfinance assistance which comprises of technological infrastructure, marketing support and the training processes among others. The various individual who came up with the Self-Help-Group or alternatively to all the other members who are present in the group for taking up the income generation roles. As such, the respondents who were chosen for the research were mainly the individual beneficiaries and the SHG members.

\section{Performance measures and variables}

The current study focused on the endeavor to evaluate the general performance of the REDPs through the reference of the physical and the financial-based performance and the socio-economic implication on the rural population. The evaluation of effectiveness and the different variables further does not have a relationship to the examination and the operational effectiveness of the selected firm and support firms while fostering their various schemes and taking all the benefits of the whole program to individual projects.

The general effectiveness of the chosen organization and the state schemes have been examined through the employment of variables like the finance support rendered, the concise number of the MSVEs that are essentially grounded, the growth of the SHGs, the training and growth programs carried out, employment generation and rural industrialization among others.

\section{Research equipment}

Due to the fact that any research is entirely based on the Primary and Secondary sources of data, the typical mathematical and statistical equipment have been employed in any place that is deemed applicable such as the Simple mean, compound yearly rate of growth, the Ratio, Ratio based examination and percentage approaches that will be employed to attain the goals.

\section{Findings and discussion}

The findings of the research are noted in relation to the stated goals that are presented in the research methodology. Some of the critical revelations in the research comprise of the following:

1. There are a significant number of development firms engaged in propelling rural entrepreneurship across the nation. Such institutions are mainly concerned with carrying out or the implementation of development programs that are either under the sponsorship of the central government or by the state government. The various schemes are fundamentally channeled and operated through such financial firms, development institutions or the agencies that are supported by the state such as the DIC or the DRDA.

2. The evaluation discovered that the DIC, DRDA and HKVIB have underperformed in relation to the promotional endeavors that are needed for the proper operationalization and also the execution of the different entrusted development agenda across India. The respondents shows that a mix of various responses concerning the creation of awareness concerning the programs through various means and were lacking in the right promotion that led into the condition in which a large number of individuals in the community were not aware concerning such fundamental programs and failed to capitalize on the opportunity to avail the advantages. 
Citation: Ullah R (2018) Brief Concepts and Philosophies of Different Authorities on the Crucial and Dynamic Aspect of Entrepreneurship in India. J Entrepren Organiz Manag 7: 249. doi: 10.4172/2169-026X.1000249

Page 6 of 6

3. The economy growth firm offered credit and financial aid and support to the various prospective rural-based entrepreneurs who availed of the advantages of the program.

\section{Conclusion}

In general, centrally sponsored rural self-employed generation based programs that have been analyzed in the context of contribution to the rural entrepreneurship development have been fostered to a large extent in the spirit of fostering social and economic scope of living and the target societies, growth of the rural sectors, developing employment chances in the rural Haryana and economic prosperity of the rural places that are still developing. According to research, entrepreneurship is largely an important element in the growth of the economy in the rural setting and societies across the country. Nonetheless, the analysis of the effects of entrepreneurship in relation to the rural economic development is limited. One main reason is the limitation of information on entrepreneurial activities.

\section{References}

1. Kirzner IM (2015) Competition and Entrepreneurship. University of Chicago press.

2. Parker SC (2018) The Economics of Entrepreneurship. Cambridge University Press.

3. Rai KB (2018) Education and Entrepreneurship: Policy Review of South Asian Countries. IJSSM 5: 60-68.

4. Backhaus JG, Schumpeter JA (2006) Joseph Alois Schumpeter: Entrepreneurship, Style and Vision. Springer Science \& Business Media.

5. Schumpeter JA, Backhaus U (2003) The Theory of Economic Development. Harvard University Press

6. Kuratko DF (2016) Entrepreneurship: Theory, process, and practice in the 21st century. IJESB 13: 8-17.

7. Meyer GD, Neck HM, Meeks MD (2017) The Entrepreneurship-Strategic Management Interface. Strategic Entrepreneurship: Creating a New Mindset, pp: $17-44$.

8. Ghani E, Kerr WR, O'connell S (2014) Spatial Determinants of Entrepreneurship in India. Reg Stud 48: 1071-1089.

9. Sarathy R, Kumar K, Eddleston KA (2015) Enterprising Families in India: Are Their Businesses and Families Enemies?

10. Selvaratnam V (2017) Article Review-National Knowledge Commission Recommendations: Follow Up Action on NKC Recommendations - A Commentary. Institutions and Economies 4: 165-174.

11. Robinson KL, Dassie W, Christy RD (2004) Entrepreneurship and Small Business Development as a Rural Development Strategy.
12. Storey DJ (2016) Entrepreneurship and New Firm. Routledge.

13. Schumpeter JA (2017) Essays: On Entrepreneurs, Innovations, Business Cycles and the Evolution of Capitalism. Routledge.

14. Agrawal A, Kumar P (2018) Social Entrepreneurship and Sustainable Business Models: The Case of India. palgrave macmillan.

15. Drucker $P$ (2014) Innovation and Entrepreneurship. Routledge.

16. Pradhan KC (2017) Unacknowledged Urbanization: The New Census Towns in India. Subaltern Urbanisation in India, pp: 39-66.

17. Subramanyam I, Kumari MS (2016) Rural Development Policies and Programmes in India. Local Government Quarterly.

18. Das RK, Misra H (2017) Policy Convergence Readiness in the Access Layer to Support Digital India: Case Based Studies. Proceedings of the Special Collection on E-Government Innovations in India, pp: 115-123.

19. Kazanjian RK, Drazin R, Glynn MA (2017) Implementing Strategies for Corporate Entrepreneurship: A Knowledge-Based Perspective. Strategic Entrepreneurship: Creating a New Mindset, pp: 173-199.

20. Dees JG (2017) Case Studies in Social Entrepreneurship and Sustainability Routledge.

21. Cornelius $B$, Landstrom $H$, Persson $O$ (2006) Entrepreneurial Studies: The Dynamic Research Front of a Developing Social Science. Entrepreneursh Theory Pract 30: 375-398.

22. Fayolle A, Kyro P, Ulijn JM (2005) Entrepreneurship Research in Europe: Outcomes and Perspectives. Edward Elgar.

23. Brenkert GG (2017) Entrepreneurship, Ethics, and the Good Society. Ethics and Entrepreneurship 3: 5-43

24. Ghani E, Kerr WR, O'Connell SD (2014) Political reservations and women's entrepreneurship in India. J Dev Econ 108: 138-153.

25. Nidheesh KB (2009) Study on the changing process of Kerala women through Kudumbashree in Kerala. International NGO Journal 4: 352-361.

26. Kalyani M, Sahoo MP (2011) Human resource strategy: A tool of managing change for organizational excellence. International Journal of Business and Management 6: 280 .

27. Krishnan L, Sequeira AH, Snehalatha M (2008) Empowerment of underprivileged women through self-help groups. Journal of Community Guidance \& Research 25: $62-74$

28. Agrawal A, Sahasranamam S (2016) Corporate social entrepreneurship in India. South Asian Journal of Global Business Research 5: 214-233.

29. Malarvizhi R (2014) Entrepreneurial Barriers and Success Factors of Women in Utility Service Businesses.

30. Rauch A, Wiklund J, Lumpkin GT, Frese M (2009) Entrepreneurial orientation and business performance: An assessment of past research and suggestions for the future. Entrepreneursh Theory Pract 33: 761-787. 